\title{
The local colleges Architectural profession education graduation design teaching thinking under CDIO principle
}

\author{
Sun Ming \\ Northeast Forestry University \\ School of civil engineering \\ NEFU \\ Harbin, China \\ 30949592@163.com
}

\author{
Liu Wei bin \\ Northeast Forestry University \\ School of civil engineering \\ NEFU \\ Harbin, China \\ 50079811@163.com
}

\begin{abstract}
Architectural graduation design, as summary of five years studies at university, is not a test of student architectural design ability, but a transitional stage into the future professional career. So the discussion of the curricula set strategy and teaching method is a further worthy research topic. The paper, based on the CDIO teaching idea, analyzed thoroughly the educational reform problems of the graduation design, puts forward the principle of graduation design topic, in the design process, increases modular courses \& the interactive discussion teaching mode, teaching system of design studio, teaching training mode of the team spirit, concrete measures. It will provide necessary teaching practices for architecture professional teaching reform.
\end{abstract}

Keywords- Architecture; CDIO principle graduation design

\section{INTRODUCTION}

Teaching process of graduation design is not the final key link of Architectural undergraduate course teaching, only is an important stage of realizing the undergraduate training objective., it is one of difficult task for local colleges how to make the students independently completes the whole graduation design process. Architecture specialty has been committed to professional education teaching reform in Heilongjiang institute of science and technology (HIST), and set the goal to explore the basic graduation design patterns, adopting the needs of society, enhancing professional skills as core, taking the student as root, these are consistent with talented person training target of "great moral education, great practice and great engineering ". Through these years of exploration, not only the profession is a bit breakthrough in the basic theory, but also the profession takes a series of effective reform measures in teaching practice, undertake many levels of the training, teaching quality get improved steadily.

\section{CDIO THEORY}

CDIO mode is an acronym namely Conceive-Design Implement - Operate. It expresses the four stages of the product development; reflect joint connection with model and the engineering production. The principle of this method is simple, content is broad and strong adaptability, therefore, it has the very strong maneuverability to evaluate engineering college students' school by using the concept of the model. It is very suitable for local colleges and universities heavy engineering practice teaching of vocational characteristic. Figure1 present course teaching system modes based on CDIO idea.

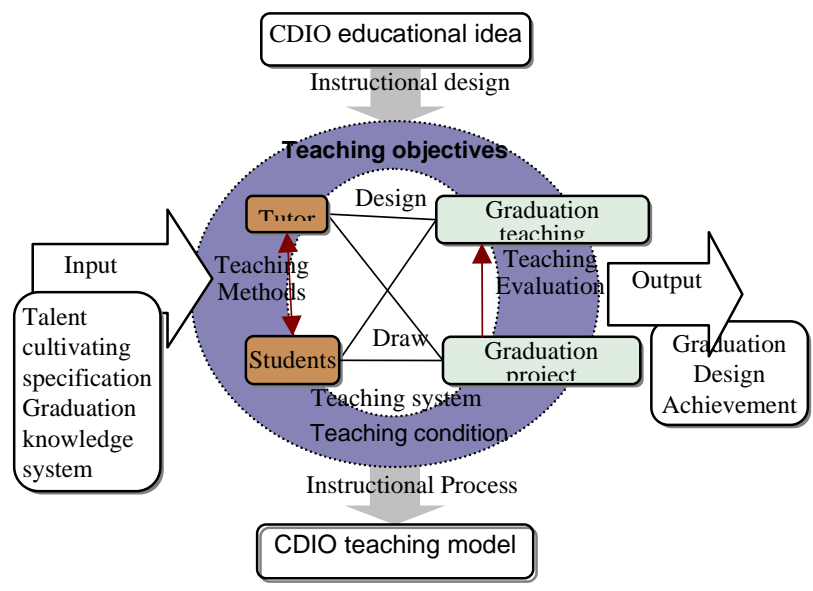

Figure 1. CDIO model content and ideas

CDIO model put forward four aspects of the specific goals and requirements of engineering education, these goals and requirements combined the current engineering involves the knowledge from "technical knowledge and reasoning", "personal and professional skills and quality", "interpersonal skills, team and communication" and "in the enterprise and the social environment ". These goals collect concerning the knowledge, skills and attitudes of the assembly in the current engineering. So in essence model contains documents that engineering college students should accept the basic demand of engineering education. [1] Figure 2 shows features of CDIO engineering idea in the enterprise and the social environment.

From the graph, model has double properties with targeted guidance and teaching outline: Firstly its goals is to provide students with more practice knowledge in the basic science knowledge and engineering basic knowledge platform, educational engineering students become the process creator and leader to implement the new products or new system, carries out conception, design, implementation and operation of engineering system; Finally model demands that engineering course teaching system is an learning 
methods based on the problem, and emphasized the inquiry, to provide a new integrated education and offer comprehensive engineering knowledge platform students contacted.

Architecture specialty of HIST selected CDIO teaching idea as the guiding ideology, making a new training goal, cultivate professional morality and law consciousness architect with the solid engineering science foundation, creative and system thinking ability, multidisciplinary background and international vision, good management and communication skills, the teaching achievement penetrated through the whole process of architecture, and got the integrated embodiment in the graduation design. Figure 3 shows architectural teaching system framework based on CDIO model.

\section{THE GRADUATION DESIGN PROBLEM}

Insufficient graduation design depth: The depth and subject setting of the graduation design are not too much essential difference from lower-grade, it expresses that the graduation design looked pale and no depth. Common phenomenon is only big flat organizational relations, lack of organization and scrutiny of detail space. In the form of organization, lack of design logic of the corresponding with the flat, on the other hand, the lack of the detailed scrutiny and design. This phenomenon develops a poor habit. When the students go into the design industry, it is harmful of the design practice in future.

Improper selection of design task. Architecture design courses have been used for "type design" teaching method, namely five years of design course ensure students get more design types, through the teaching from simple to the complex arrangements, make students gradually grasp and understand the principle and method of design. Until the graduation design phase, the whole teaching idea is still the continuation of this approach, but the issue itself is more complicated. [2]

There are great disharmonious and inconsistent between students' graduation design attitude and design requirements relatively. Architectural design forms are closely related to the environment, the whole designs are a logical reason system from the plane to the 3D space. Absolutely these do not follow one's inclinations. Numerous design programs follow rules of traditional path from plane to space, avoid following innovative way from space to form. The designs should be a complete and thorough creative enthusiasm works, not be flaring impracticable plagiarism at practice. [3]

\section{GRADUATION DESIGN PROGRAM}

Graduation design is not the last class of students to participate in social practice, but is important segment of teaching integrate with the world market. In fact the graduation design should be a creative process. And is a teaching process of innovation and research to realize works comprehensive and feasible. Graduate design teaching should stress particularly operating procedures that design process and method, and also should have enough attention to theory and innovation. The design methods and design process is an innovation in leading of design theory, so the graduation design goals should be complementary to process training and the requirements of the training method. Table 1 expresses plan of graduation design based on CDIO engineering idea. Schedule of graduation design are given in Table 1.

TABLE I. SCHEDULE OF GRADUATION DESIGN BASED ON CDIO PRINCIPLE

\begin{tabular}{|c|c|c|c|}
\hline \multicolumn{2}{|c|}{ Design stage } & \multirow{2}{*}{$\begin{array}{c}\text { Instruction keynote } \\
\begin{array}{c}\text { participate in a complete } \\
\text { projects }\end{array}\end{array}$} & \multirow{2}{*}{$\begin{array}{c}\begin{array}{c}\text { Instruction } \\
\text { method }\end{array} \\
\begin{array}{c}\text { Discuss } \\
\text { graduation } \\
\text { topic }\end{array}\end{array}$} \\
\hline Conceive & practice & & \\
\hline & Topic & $\begin{array}{l}\text { Discussion topic } \\
\text { selection direction }\end{array}$ & $\begin{array}{l}\text { To write plan } \\
\text { descriptions }\end{array}$ \\
\hline \multirow{2}{*}{ Design } & Collection & Site situation data & $\begin{array}{l}\text { Team work } \\
\text { discuss }\end{array}$ \\
\hline & Practice & $\begin{array}{l}\text { Around the subject } \\
\text { practice }\end{array}$ & $\begin{array}{l}\text { typical type } \\
\text { investigation }\end{array}$ \\
\hline \multirow{3}{*}{ Expression } & $\begin{array}{l}\text { Early } \\
\text { design }\end{array}$ & Architectural conception, & Team work \\
\hline & Mid design & Building sketch & $\begin{array}{l}\text { focus on the } \\
\text { scheme }\end{array}$ \\
\hline & Late design & $\begin{array}{l}\text { Architectural details } \\
\text { processing }\end{array}$ & $\begin{array}{l}\text { independent } \\
\text { thinking }\end{array}$ \\
\hline Implement & Thesis & $\begin{array}{l}\text { Architectural drawing, } \\
\text { thesis }\end{array}$ & $\begin{array}{c}\text { Independent } \\
\text { drawing }\end{array}$ \\
\hline \multirow{2}{*}{ Operation } & Defence & Orderly discussion, & $\begin{array}{l}\text { Preview } \\
\text { defence }\end{array}$ \\
\hline & Evaluation & $\begin{array}{l}\text { Design innovation, } \\
\text { feasibility }\end{array}$ & $\begin{array}{l}\text { Summarize } \\
\text { the results }\end{array}$ \\
\hline
\end{tabular}

From the table1, the graduation design has a relatively clear target system, including of the final result goals, the process goals and objectives. The graduation design pay close attention to Architectural design method and thinking mode. Figure 4 demonstrate the graduation design forms process.

\section{GRADUATION DESIGN TOPIC SELECTION}

To improve reality of Architectural design topic: Graduation design topic selection regards doing real project as the leading way. Sources include teachers hosted the actual project and students participated the actual engineering, familiarize students with operating procedures of practical engineering and get them to be a comprehensive actual experience. [4]

Comprehensiveness of design title choice: Design topic choice must meet the basic teaching requirements, have one certain guarantee of engineering training, and improve the students' comprehensive ability \& design level; Topic should as far as possible combine with the actual production, the scientific research, and promote the teaching and scientific 
research the organic integration. Meanwhile, the topic selection should be improving greatly all kinds of students in the original level and ability, encouraging part of the excellent students to innovate in design. [5]

To choose suitable design topic: Every graduation design teams should be more focus on the different directions according to coordinate teachers design specialty and students interests, own development orientation, form the specific research direction and advantage. Some focus on the high-rise building technology, some turn to the relationship between the city and the building, others focus on cold culture, the local building, etc. Creative thinking of architectural design make different people plan has different results, with the same features, the same conditions. Therefore, students need to be encouraged to add subtitle, choose the research direction and improve their creative thinking ability. [6]

\section{THE GRADUATION DESIGN PROCESS}

To strengthen management of the graduation design process: The process are divided into early, middle and late three stages, in the instruction, each process must clear mission, set goals, and put forward the corresponding quality requirements. [7]

Opening teaching modes in the process of graduation design. Graduation design should be diversified in teaching methods and means, the corresponding teaching mode should also be open. They not only reflect in the future that students can independently choose the design subject and tutors, but also embodies that part of the subsidies can provide by social unit in the process of graduation design, and the cooperation with design group will run through the whole process of graduation design. [8]

Training quality in the design process: As head of construction project, the architect has more comprehensive knowledge and quality. To pay attention to the building solid professional knowledge, teacher also can not ignore other related training. At the same time, teachers focus on students' writing ability training in each stage of the design, in addition to require students to submit the necessary drawing, also provide the corresponding text, such as literature review, design concept and feasibility report, design research papers, graduation design specifications, etc. Some students of potential leader are assigned to the head of the group as a subject, let the students help the teacher supervise this group of graduation design progress, coordinate relationship between both lectures and plan, organization conference, improve the management of students ability, strengthen the cooperation spirit among students.

\section{CONCLUSIONS}

The teaching modes effectively resolve the graduation design theory \& practice teaching in the learning process, each student has its own mission, have to accept the inspection and assessment, performance rating pays attention to process evaluation, effective in stimulating the interest, improve the learning efficiency, knowledge, strong, but constructs a better learning environment, still can exercise the student the various ability, work for the students' future lay the good foundation.

\section{ACKNOWLEDGMENT}

This work was financially supported by key project funds for Heilongjiang provincial education \& science planning project. ( GBB1212001 ) \& Heilongjiang provincial education science and planning research funds for Higher education association China. (HGJXH C110892)

\section{REFERENCES}

[1] Edward F Crawley. The CDIO Syllabus-A Statement of Goals for Undergraduate Engineering Education[R]. The MIT CDIO Syllabus Report, 2001

[2] Crawley, Edward F, Malmqvist, Johan, Ostlund, Brodeur, Doris R.: Rethinking Engineering Education. The CDIO Approach. Springer Science+Business,pp:1-286,2007

[3] Sun Ming, Liu Weibin, Study on Teaching Mode of Urban Planning Specialty Graduation Design based on CDIO in colleges[C].ICASS 2013, pp:229-233,2013

[4] Bao Jiasheng. Opinions of Teaching Reformation of Architectural Design-84'Suggestions of Architectural Design Teaching Reformation of SEU [J]. New building, 2006, (3): 110-111. (In Chinese)

[5] Bu Zhengwei. Type of Architect and Training of design-serving Architect-a Substantial Issue in Architectural Education during Transitional Period [J]. New building, 2004, (1):88-89. (In Chinese)

[6] Yang Li Jun, He Zhi-Juan. Study and practice on the local colleges' graduation project in civil engineering specialty [J]. Shanxi building, 2007,33, (4):214-215. (In Chinese)

[7] Sun Ming, Liu WeiBin, WangYuFen. Rearch on Teaching Mode of Universities Urban Planning Specialty Graduational Design based onCDIO [J]. The forest engineering, 2012, (5):92-96. (In Chinese)

[8] Yang GuangJie. the research and exploration on teaching reform of urban planning design course [J]. Planners, 2011, (10) : 111-114.(In chinese). 


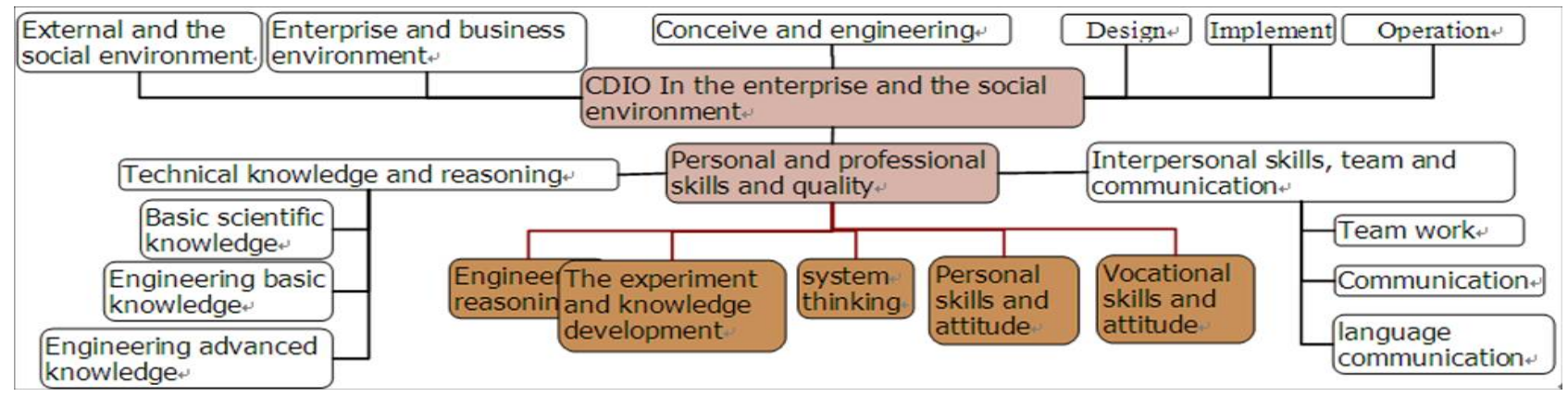

Figure 2. CDIO in the enterprise and the social environment

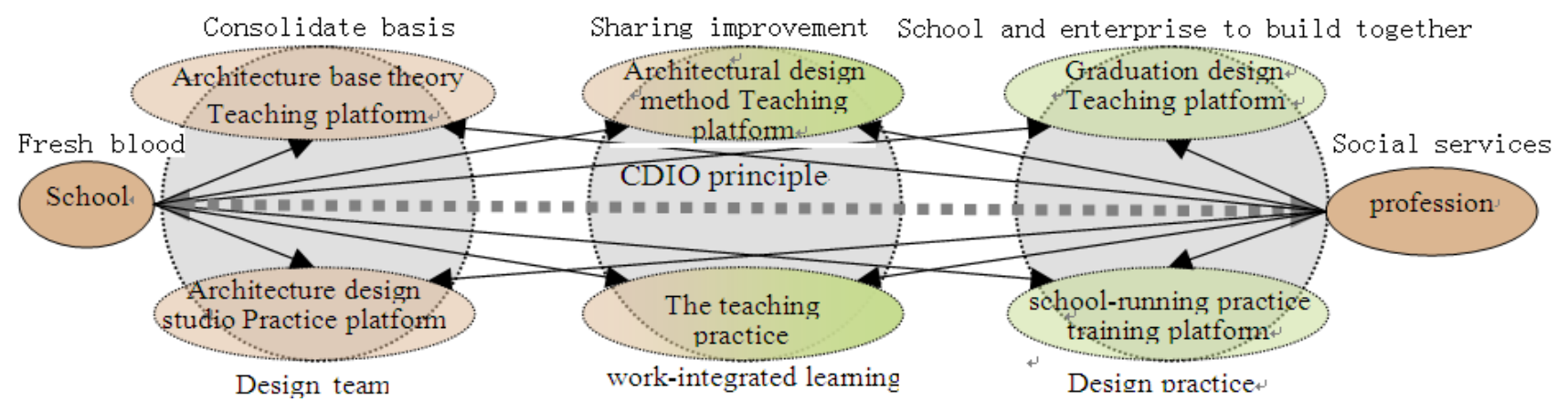

Figure 3. Architecture teaching system framework based on CDIO concept

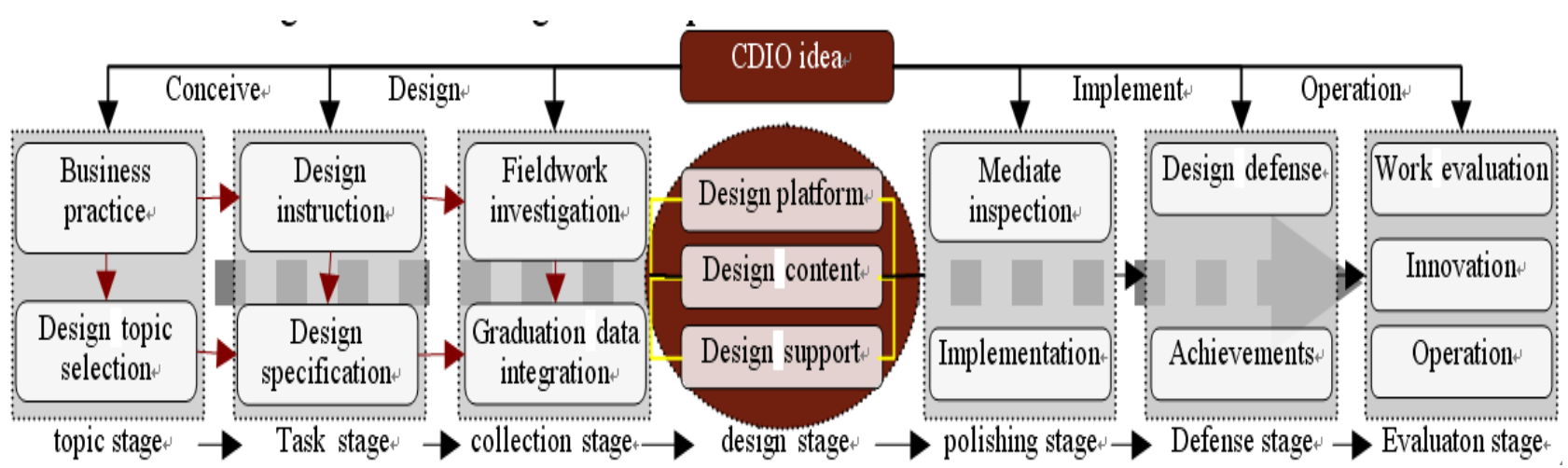

Figure 4. Graduation design program diagram of architecture based on CDIO idea 